\title{
Quantification of gene expression in methanotrophs by competitive reverse transcription-polymerase chain reaction
}

Jong-In Han and Jeremy D. Semrau*

Department of Civil and Environmental Engineering, The University of Michigan, 1351 Beal Avenue, Ann Arbor, Michigan 48109-2125, USA.

\section{Summary}

To improve the monitoring of methanotrophic activity, a competitive reverse transcription-polymerase chain reaction (RT-PCR) methodology was developed. Homologous internal RNA standards were created for mmoX and $p m o A$, genes encoding polypeptides of sMMO and pMMO, respectively. Using specific primer sets, expression of SMMO and pMMO could be quantified by means of competitive RT-PCR and capillary electrophoresis with uncoated bare-fused silica columns and UV detection. Using this technique, it was discovered that the amount of mRNA transcript for both $m m o X$ and $p m o A$ correlated well with whole-cell sMMO and PMMO activity respectively. A method for soil RNA extraction was also developed to utilize this RNA quantification technique for the monitoring of methanotrophic activity in situ. In a model soil slurry system with a background concentration of $2.9 \mu \mathrm{M}$ copper, it was found that only $p m o A$ was transcribed by cells capable of expressing both forms of MMO. As PMMO and SMMO have very different substrate ranges and kinetics, this methodology may prove useful for optimizing in situ bioremediation by methanotrophs. Provided sufficient sequence information is available to create specific primer sets, these techniques can be applied for monitoring and measuring the activity of other microbial communities in situ.

\section{Introduction}

Measurement of specific gene expression is becoming increasingly important for environmental as well as clinical purposes (Meckenstock et al., 1998; Freeman et al.,

Received 14 August, 2003; revised 27 October, 2003; accepted 10 November, 2003. *For correspondence. E-mail jsemrau@ umich.edu; Tel. (+1) 734764 6487; Fax (+1) 7347632275.

(C) 2004 Blackwell Publishing Ltd
1999; Wilson et al., 1999). Even though traditional DNA methods, such as the analysis of $16 \mathrm{~S}$ ribosomal DNA and functional genes, can help determine microbial diversity and identify particular microbial abilities (von Wintzingerode et al., 1997; Hill et al., 2000), they provide relatively little information on the ecological significance of microorganisms as DNA is known to be stable even in dead cells (Lindahl, 1993). Compared with DNA methods, analysis of specific gene expression by monitoring mRNA levels can provide one with information as to the activity of cells as a result of the short half life of mRNA $(\sim$ minutes) provided regulation is primarily at the level of transcription (Kusher, 1996; Sheridan et al., 1998; Spring et al., 2000). One powerful approach for mRNA detection is RT-PCR, the combination of reverse transcription (RT) and polymerase chain reaction (PCR). Reverse transcription-PCR has proven to be a potent tool able to detect mRNA, which may be undetectable by other techniques (Ferre, 1992). One methodology to quantify mRNA levels, competitive RT-PCR, uses a fixed amount of target RNA that is reverse-transcribed and amplified together with varying amounts of an internal RNA standard using the same primer set in the same reactions. The quantity of target RNA is then determined by measuring the amounts of target and standard products resulting from RT-PCR.

The products from competitive RT-PCR can be separated by slab gel electrophoresis, stained, scanned and analysed. However, slab gel electrophoresis requires a relatively long time and is not easily automated, and thus is of limited use for quantification. Recently, capillary electrophoresis (CE) has been proposed for convenient quantification of PCR products (Lehmann et al., 1997; Sunada and Blanch, 1997; Beck et al., 1999; Rechards et al., 2000). Compared to slab gel electrophoresis, CE has several advantages such as complete automation from sample injection to data analysis, fast separation, small sample requirement, on-column detection, as well as high precision and accuracy.

Although this RNA quantification technique has significant potential, its successful application for environmental samples can be accomplished only with an efficient, quantitative RNA extraction method from soils. Such extractions suffer from compounded inefficiencies caused by 
incomplete cell lysis, RNA degradation by ubiquitous RNases, sorption onto soil surfaces, and co-extraction of humic materials that affect enzymatic activity (Lorenz and Wackernagel, 1987; Moran et al., 1993; Alm and Stahl, 2000). In recent years, a number of RNA extractions from soils have been attempted but they were primarily qualitative (Borneman and Triplett, 1997; Fleming et al., 1998; Miskin et al., 1999; Alm and Stahl, 2000).

The primary goal of our study was to develop a useful competitive RT-PCR methodology to accurately monitor in situ microbial function and activity. To achieve this goal, we developed an accurate, fast, and convenient analysis of RT-PCR products using CE as well as another method for RNA extraction from soils. To test these methodologies, the expression of MMO in methanotrophs was examined but these techniques can be applied to any cell of interest provided enough information is available to develop specific primer sets.

Methanotrophs are Gram-negative bacteria that utilize methane for both carbon and energy. These bacteria can co-metabolically oxidize halogenated hydrocarbons through the non-specific nature of the methane monooxygenase (MMO) (Hanson and Hanson, 1996; Oldenhuis et al., 1989; Han et al., 1999). Two distinct types of MMO, however, have been found to exist with very different substrate ranges and kinetics. At low copper to biomass ratios, some methanotrophs can synthesize a cytoplasmic or soluble methane monooxygenase (sMMO). Soluble methane monooxygenase has relatively fast degradation kinetics and a broad substrate range including alkanes and alkenes up to eight carbons in length, simple haloalkane and alkene, and aromatic and alicyclic compounds (Stirling et al., 1979; Burrows et al., 1984). At copper-tobiomass ratios greater than $0.89 \mu \mathrm{mol}$ copper.(g cell dry weight $)^{-1}$, these cells express a membrane-bound or particulate methane monooxygenase (pMMO) and in fact most known methanotrophs can only express pMMO and do so constitutively (Hanson and Hanson, 1996). Particulate methane monooxygenase, even though expressed in all known methanotrophs, has slower degradation kinetics and a narrower substrate range and is only able to oxidize alkanes and alkenes with up to five carbon atoms and some halogenated hydrocarbons (Burrows et al., 1984; Han et al., 1999). As methanotrophs are commonly found at $\mathrm{CH}_{4}$ :air interfaces; they have been extensively examined for biodegradation of hazardous wastes (Oldenhuis et al., 1989; Han et al., 1999). The two forms of MMO have very different kinetics and substrate ranges; therefore, one should know what form of MMO is being expressed in situ to optimize methanotrophic bioremediation schemes.

The genes for both sMMO and pMMO have been found in operons (Murrell, 1992; Semrau et al., 1995; Stolyar et al., 1999). Of the five known genes encoding polypep- tides of sMMO, mmoX, the gene encoding a subunit of the hydroxylase component, has been extensively used for PCR amplification of methanotrophic DNA from many environments (McDonald et al., 1995; Murrell et al., 1998). Similarly $p m o A$, the gene encoding the polypeptide believed to contain the active site of $\mathrm{pMMO}$, has also been extensively examined for PCR manipulations (McDonald and Murrell, 1997; Cheng et al., 1999). These genes are highly conserved among known methanotrophs, thus they were chosen to develop a methodology for competitive RT-PCR of mRNA.

\section{Results}

\section{Separation by CE}

Double-stranded DNA fragments of known size (Roche Molecular Biochemicals, Indianapolis, IN) were successfully separated using a newly developed CE protocol as shown in Fig. 1A (see Experimental procedures for more information). This protocol demonstrates a faster method over conventional slab gel electrophoresis. In this system, DNA fragments of 19-1114 bp were separated within 21 min. Separation time could easily be shortened for analysis of RT-PCR products of $p m o A$ and mmoX standards and targets (approximately 450-500 bp in size) by increasing voltage to $8 \mathrm{kV}$; thus, separation could be done within $8 \mathrm{~min}$ (data not shown).

\section{Competitive RT-PCR}

For the accurate quantification of mRNA in competitive RT-PCR, one must be able to separate the target and standard RT-PCR products as well as have them both amplified with the same efficiency over a range of cycles. An example of the use of CE for separation of target and standard RT-PCR products is shown in Fig. 1B. As can be seen in this figure, as the ratio of target to standard for pmoA was varied from 0.03 to 2.0 , a corresponding change in the electropherograms was seen with the target being preferentially amplified. To further demonstrate that both the targets and standards of $p m o A$ and $m m o X$ were amplified with equal efficiency, competitive RT-PCR was performed using targets and standards at approximately equivalent concentrations for 27-35 PCR cycles. As can be seen in Fig. 2, amplification of both target mRNA and standard RNA was found to proceed with equal efficiency for this range of PCR cycles.

In Fig. 3, typical competitive RT-PCR analyses of $m m o X$ and $p m o A$ mRNA transcripts in a total RNA sample from pure cultures of $M$. trichosporium OB3b are shown. In these analyses, the log ratio of amplified target to amplified standard was plotted against the log amount of standard added to the RT-PCR reaction. As can be seen in 
A

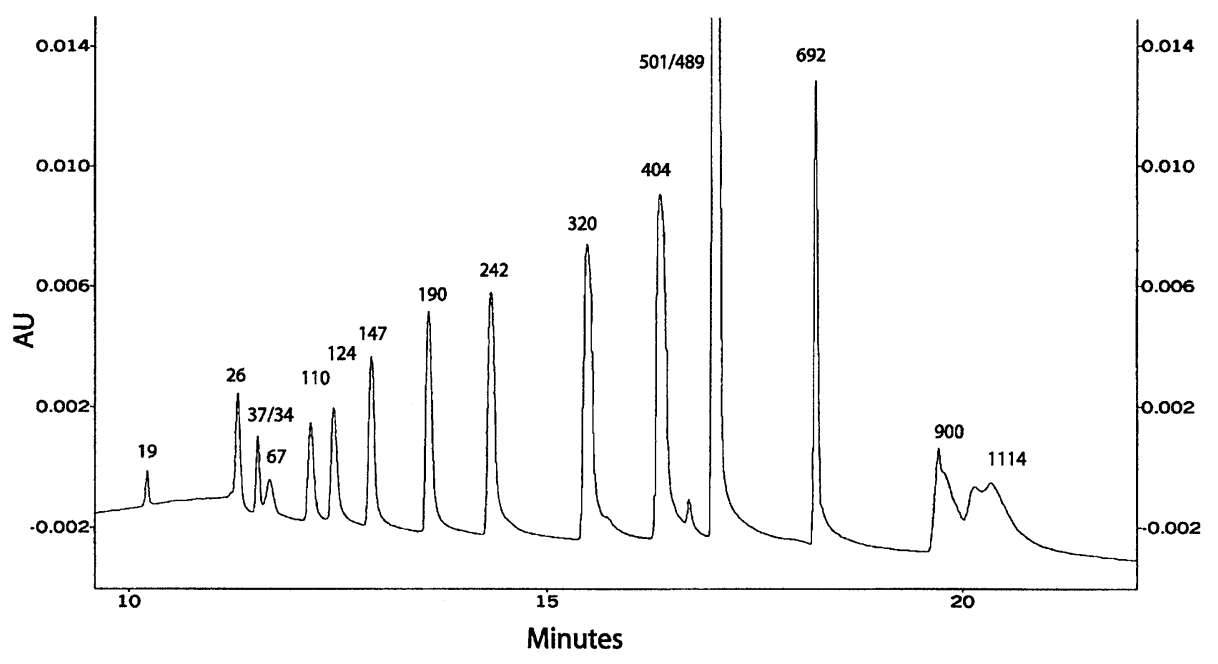

B
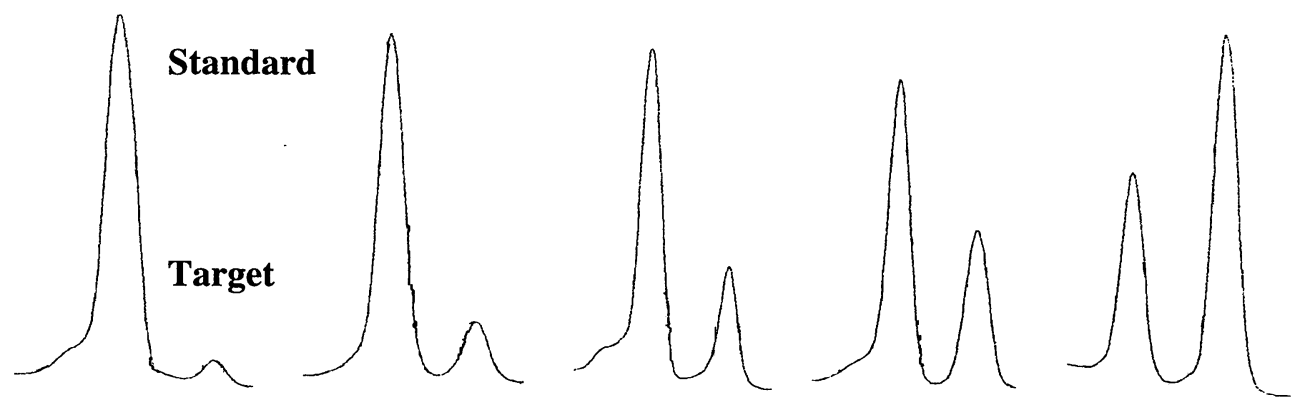

Target to Standard ratio:

0.03

0.14

0.26

0.5

2

Fig. 1. Separation of DNA molecular weight standards in an uncoated capillary column filled with HEPES-boric acid buffer system containing $0.5 \%$ HPMC, $6 \%$ mannitol and $1 \mu \mathrm{g} \mathrm{ml}^{-1}$ ethidium bromide.

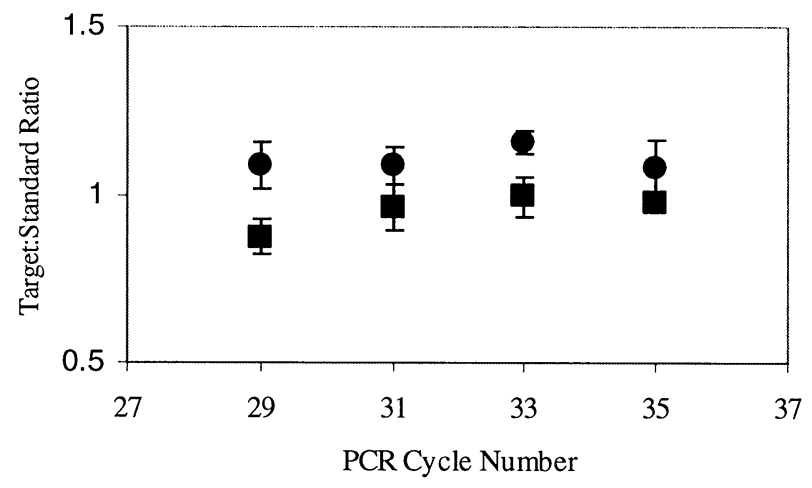

Fig. 2. Validation of RT-PCR efficiencies of $p m o A$ target:standard ratios (घ) and $m m o X$ target:standard ratios $(\mathbf{O})$. Error bars indicate the range of duplicate samples.
Fig. 3, a linear trend was observed over the range of standard concentrations used, indicating that both target and standard templates were reverse transcribed and amplified with similar efficiencies. As the data span the value at which both target and standard were amplified

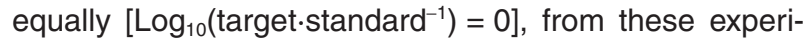
ments the level of $m m o X$ and $p m o A$ mRNA transcripts can be determined to be the corresponding amount of standard mRNA ( $10^{-16.5}$ and $10^{-15.7}$ moles, respectively). This methodology also worked for $M$. capsulatus Bath, which has the operons for both SMMO and pMMO, and M. album BG8, which only has the genes for pMMO (Fig. 4). These methanotrophs differ both physiologically and phylogenetically from $M$. trichosporium OB3b.

After a working technique was developed for the extraction of mRNA followed by the quantitative assessment of 
A

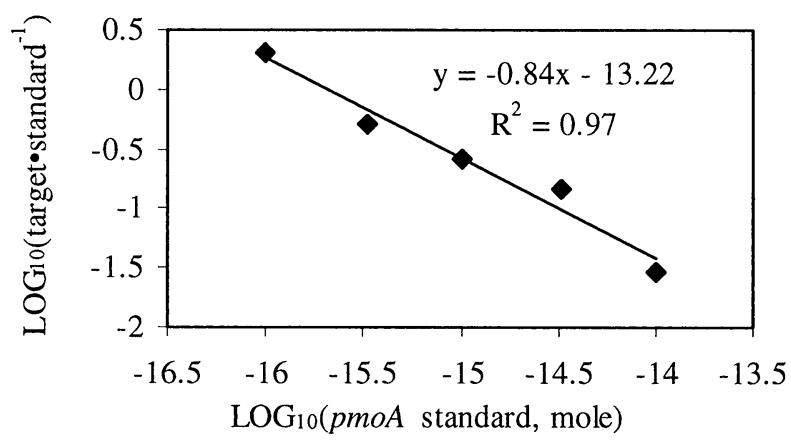

B

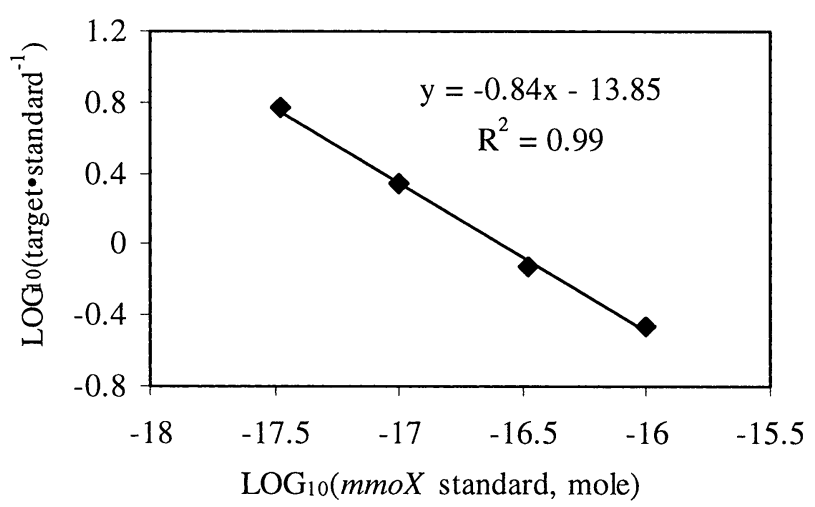

Fig. 3. Representative results of competitive RT-PCR for: (A) $p m o A$ and (B) mmoX from pure cultures of $M$. trichosporium OB3b. Cells expressing pMMO were grown in the presence of $10 \mu \mathrm{M}$ copper, whereas no copper was added for sMMO expression.

the level of $p m o A$ and $m m o X$ expression for a variety of methanotrophs, we next correlated whole-cell methane consumption rates with mRNA levels. As can be seen in Fig. 5, whole-cell methane consumption rates varied linearly with mmoX and $p m o A$ transcript levels in $M$. trichosporium OB3b when this cell was in the exponential growth phase either with no copper or $10 \mu \mathrm{M}$ copper respectively. The slope of the regression indicates the relationship between whole-cell activity to the level of mRNA transcripts. It should be noted that this relationship for this cell expressing pMMO is over twice as great of the specific activity when expressing sMMO. It appears that for this cell that more translational products may be made for each $p m o A$ transcript at a growth concentration of $10 \mu \mathrm{M}$ copper than for each $m m o X$ transcript made in the absence of copper.

In the previous experiment, the cells were in the exponential phase of growth. It is possible that cells in other growth phases, although active, may have a different relationship between whole cell methane consumption and mRNA transcript level. This possibility was investigated for
M. trichosporium OB3b. For these experiments, cells were grown in sterile groundwater amended with $0.1 \times$ NMS to simulate growth in aquifers. The growth of $M$. trichosporium OB3b was monitored by the optical density at $600 \mathrm{~nm}$ in gas tight side-arm flasks. Aqueous samples were collected several times during its growth, including when the cells entered the stationary phase as indicated by no change in $\mathrm{OD}_{600}$ as well as in the death phase as indicated by the reduction of colony forming units (CFU) in Fig. 6A and $\mathrm{B}$. For these samples, both whole-cell methane oxidation rates and $\mathrm{MMO}$ expression were measured. Because of the growth conditions ( $2.9 \mu \mathrm{M}$ copper), only

A
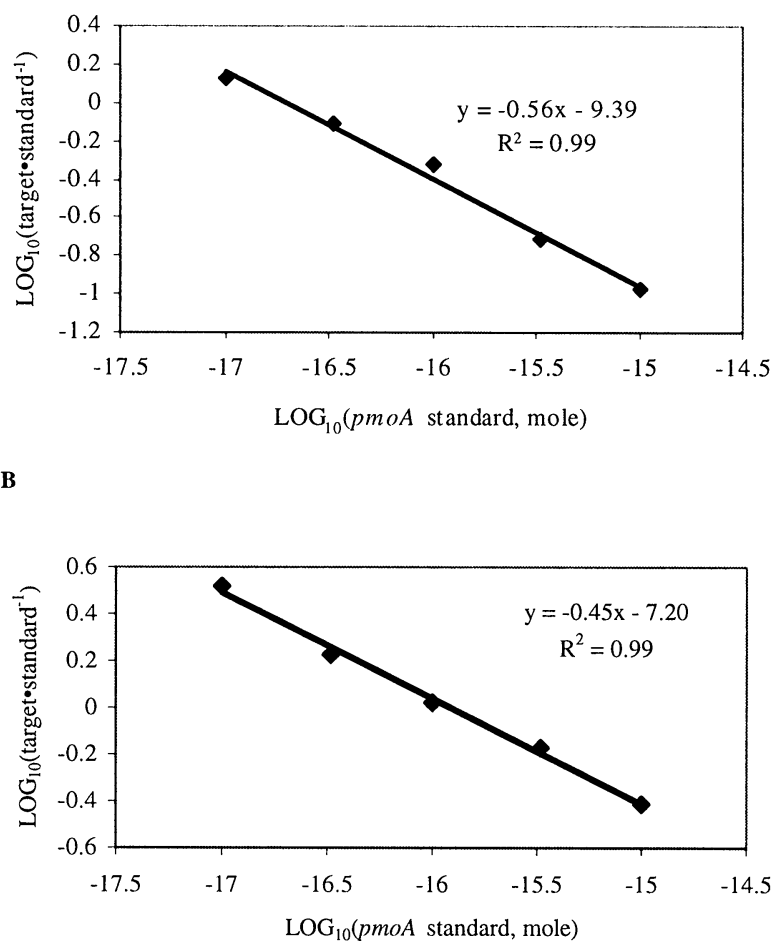

C

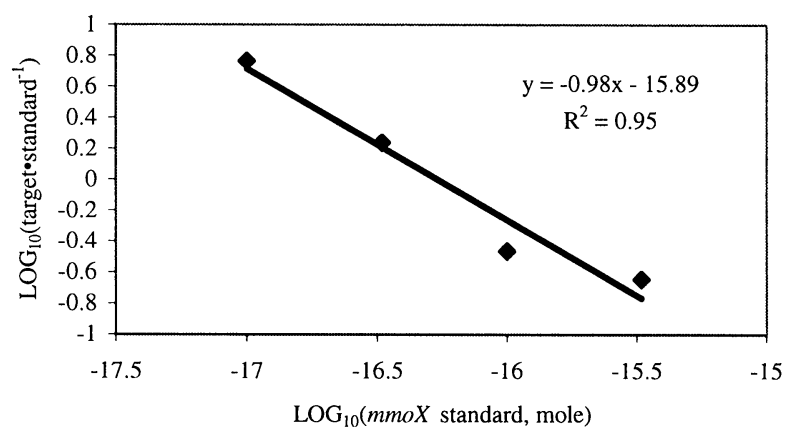

Fig. 4. Quantitative RT-PCR of (A) pmoA from Methylomicrobium album BG8; (B) pmoA from Methylococcus capsulatus Bath, and (C) mmoX from $M$. capsulatus Bath. 

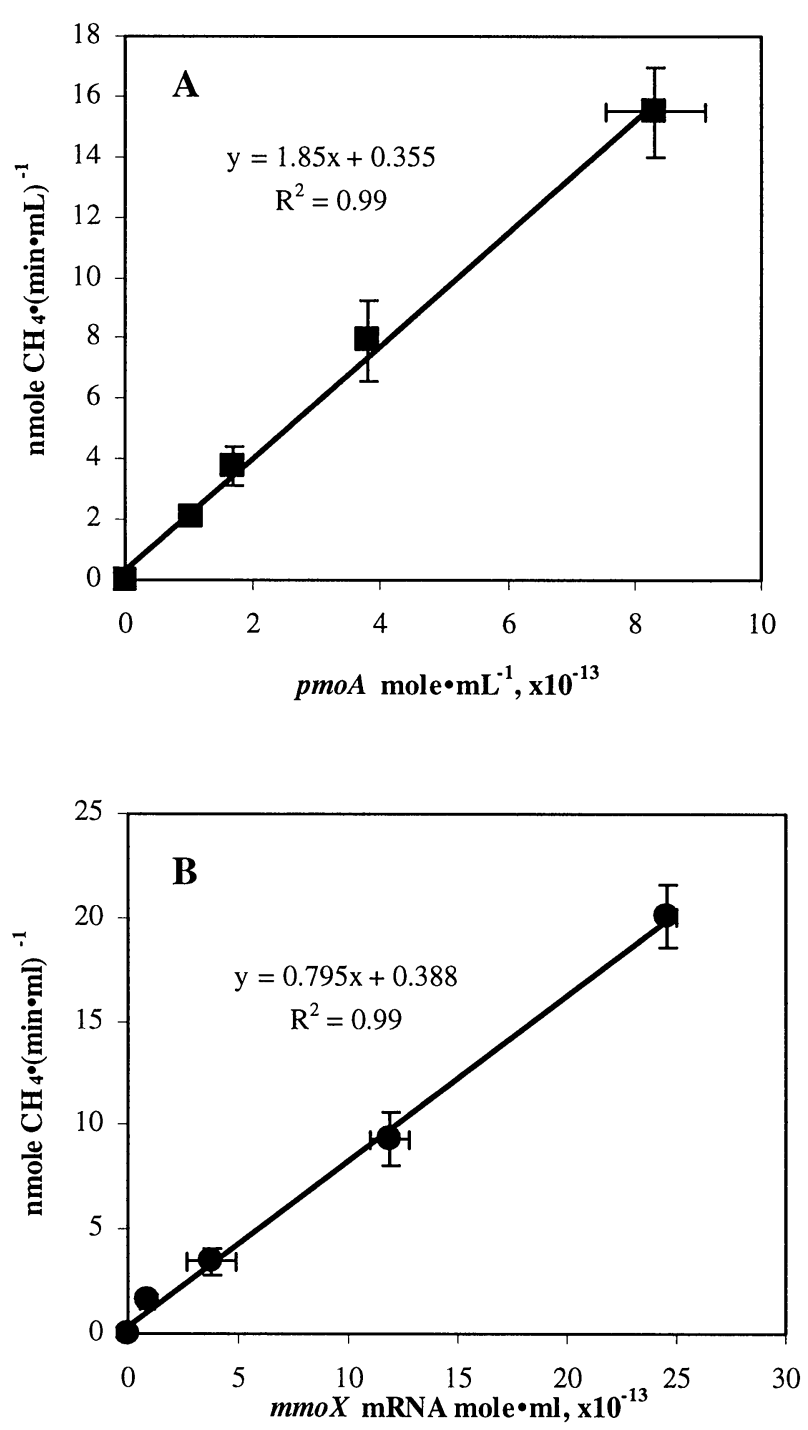

Fig. 5. Correlation of mRNA transcript levels in exponentially growing cells of $M$. trichosporium OB3b with whole-cell methane consumption rates grown with either (A) $10 \mu \mathrm{M}$ copper for expression of $p m o A$, or (B) no added copper for expression of $\mathrm{mmoX}$.

$p m o A$ expression was observed. As can be seen in Fig. $6 \mathrm{~B}$, the rate of methane consumption as well as levels of $p m o A$ mRNA correlated with the number of CFUs. Furthermore, as shown in Fig. 6C, whole-cell methane consumption again correlated with mRNA levels, indicating that RT-PCR can be used to estimate methanotrophic activity in multiple growth phases. It should noted, however, that the specific activity of $M$. trichosporium OB3b in the stationary phase indicated by the slope of the best-fit line of Fig. 6C was much greater than that found for the same cell in the exponential phase. This may be the result of the growth concentration of copper as it has been shown to exert a stronger influence on $p m o A$ expression than on whole-cell pMMO activity. Other studies have shown pmoA mRNA levels increased over 12-fold when copper concentrations were increased from 1 to $25 \mu \mathrm{M}$, but whole methane consumption rates increased by only approximately $70 \%$ over the same range of copper concentrations (Choi et al., 2003).

\section{Quantification of soil RNA}

For the extraction of mRNA from soil, the soil itself was used as matrix on which RNA can be bound and then recovered after removal of organic contaminants. Wagner soil, an aquifer soil composed of sand and low organic matter was spiked with $M$. trichosporium OB3b. RNA was isolated after cell growth in soil slurries by loading soil samples directly on a QIAGEN column in which a pierced sample tube was placed on top of the column in a $15 \mathrm{ml}$ screw-cap polypropylene tube and washing both the column and all particles with QIAGEN washing buffers and then recovering RNA sorbed on both the soil and zirconia/ silica beads with RNase-free water. With this methodology, approximately $1.50 \pm 0.3 \mu \mathrm{g} \mathrm{mRNA} / \mathrm{g}$ soil was recovered from methanotrophic incubations with Wagner soil with extraction times of approximately $1 \mathrm{~h}$. This is an improvement over the standard QIAGEN protocol in which $0.85 \pm 0.11 \mu \mathrm{g} \mathrm{mRNA} / \mathrm{g}$ soil recovered from a $2.5 \mathrm{~h}$ extraction.

Even though the modified QIAGEN column method could effectively remove brown coloured materials from crude RNA extracts, which were RT-PCR amplifiable, bovine serum albumin (BSA) was added to reduce inhibition of both reverse transcriptase and DNA polymerase (Kreader, 1996). The effect of BSA is shown graphically in Fig. 7 on a conventional slab gel. In this figure, the use of $400 \mathrm{ng} \mathrm{BSA} \mu \mathrm{l}^{-1}$ to the RT-PCR mixture enhanced RTPCR amplification significantly and had the added benefit of circumventing extensive purification procedures that might lead to loss of RNA samples by either the procedure itself or RNase attack (von Wintzingerode et al., 1997).

Based on these approaches, the quantification of $p m o A$ and mmoX mRNA transcripts in a soil sample was measured via competitive RT-PCR and CE. In this model system, only $p m o A$ transcript could be quantified $\left(5 \times 10^{-19}\right.$ mole $p m o A$ mRNA/g soil) (Fig. 8), as mmoX transcripts were not detected. This result was confirmed by the successful amplification of mmoX standard RNA, indicating that the absence of RT-PCR products of mmoX transcript was not due to the inhibition of enzymatic activity by impurities in the RNA sample (data not shown).

\section{Discussion}

Reverse transcriptase-PCR techniques have been widely 

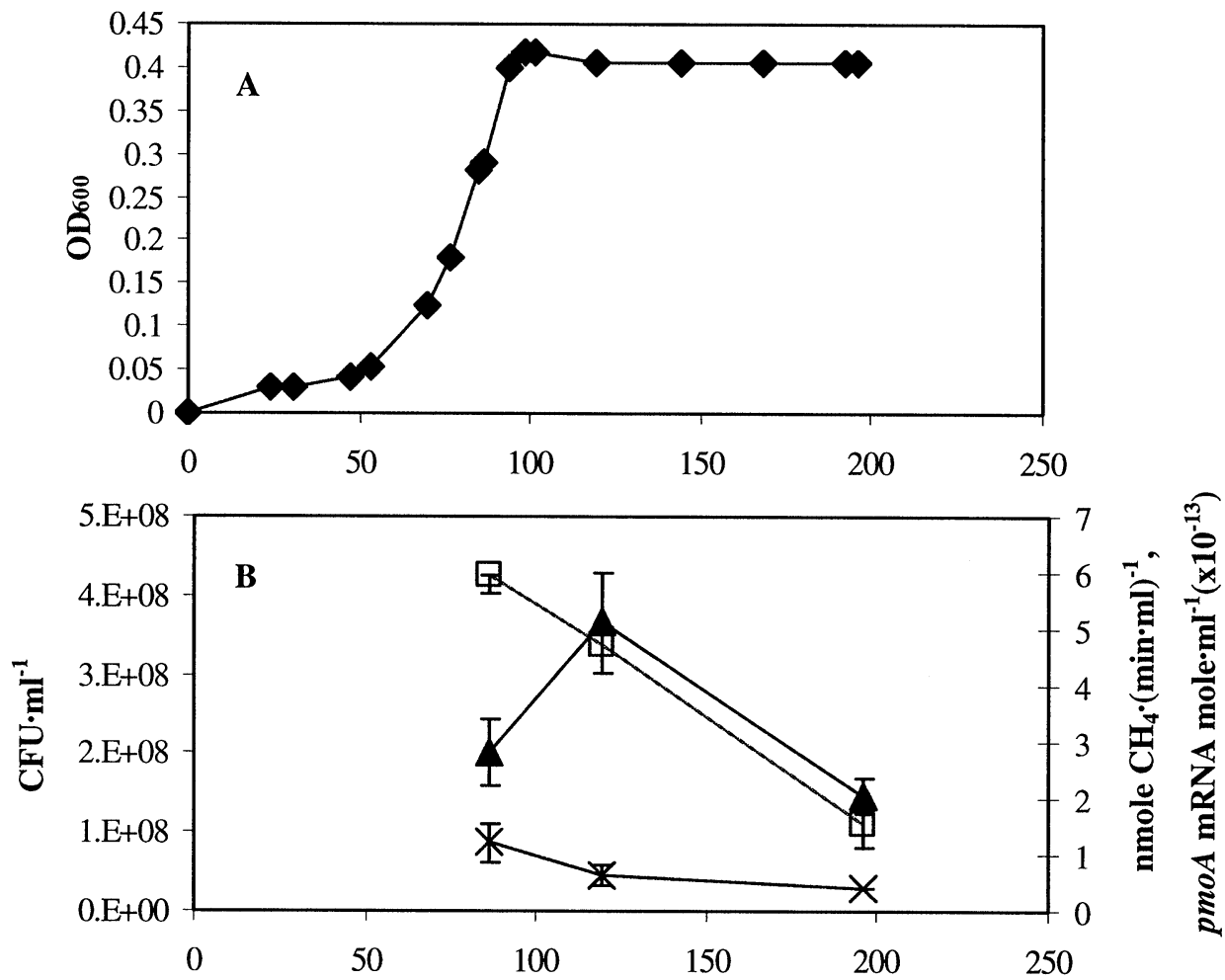

Time (hrs)

$\triangle \mathrm{CFU} / \mathrm{ml} \longrightarrow$ Activity $\rightarrow$ mRNA

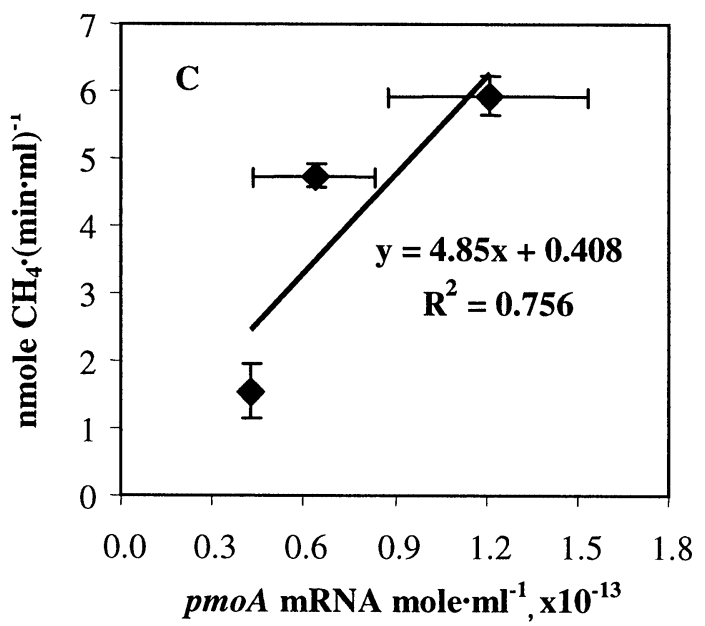

Fig. 6. Correlation of $p m o A$ mRNA transcript levels of $M$. trichosporium OB3b in both the exponential and stationary growth phases with whole cell methane oxidation rates. Cells were grown in sterile groundwater amended with $0.1 \times$ NMS with a concentration of $2.9 \mu \mathrm{M}$ copper.

used to study gene expression for clinical applications (Freeman et al., 1999) and are becoming popular for the detection and monitoring of in situ gene expression for environmental applications because of their high sensitivity and specificity (Meckenstock et al., 1998; Miskin et al., 1999; Wilson et al., 1999; Nogales et al., 2002; Alfreider et al., 2003; Bürgmann et al., 2003). To date, however, there have been relatively few attempts to apply quantitative RT-PCR techniques for environmental analyses, and those are typically semiquantitative. Previous research quantifying mRNAs in fungal species with competitive RTPCR used DNA fragments as competitors (Bogan et al., 


\section{$\begin{array}{lllllllllllll}M & 1 & 2 & 3 & 4 & 5 & 6 & 7 & 8 & 9 & 10 & 11 & 12\end{array}$}

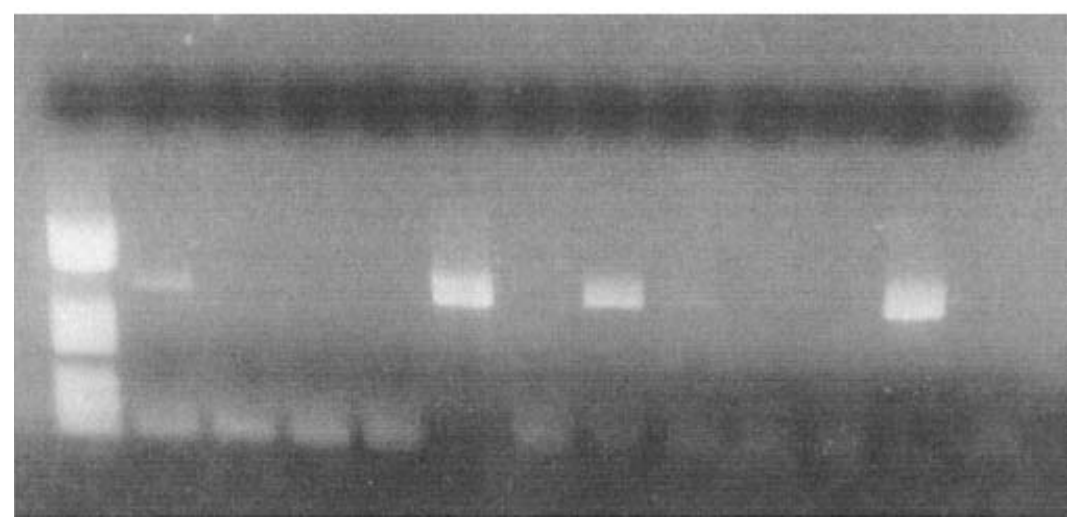

Fig. 7. RT-PCR of $p m o A$ from Wagner soil incubated with $M$. trichosporium OB3b: M, DNA size marker; $1,10^{-1}$ dilution; $2,10^{-2}$ dilution; 3 , $10^{-3}$ dilution; $4,10^{-4}$ dilution; 5 , positive control; 6 , negative control; $7,10^{-1}$ dilution w/BSA; 8 , $10^{-2}$ dilution w/BSA; $9,10^{-3}$ dilution w/BSA; 10 , $10^{-4}$ dilution w/BSA; 11 , positive control; 12 , negative control. For the positive control, RNA from pure cultures of $M$. trichosporium OB3b grown in the presence of $10 \mu \mathrm{M}$ copper was added, and for the negative control, no extract was added.
1996). This unfortunately cannot compensate for the inherent variability in the RT step (Freeman et al., 1999). Others have used a homologous RNA standard. For the estimation of the target mRNA concentration, however, a semi-absolute approach was used in which the target mRNA concentration was estimated from the dilution step at which RT-PCR products of both standard and target mRNAs were present in equal amounts (Meckenstock et al., 1998). For competitive RT-PCR to have high quantitative accuracy, one should use either a standard curve method or a plot of the log of standard signal/target signal versus the log of input RNA standard (Tsai and Wiltbank, 1998; Freeman et al., 1999).

mRNA quantification from environmental samples by means of competitive RT-PCR has an obvious advantage in that it prevents potential tube-to-tube variations during the procedure, and also compensates for PCR-inhibitory effects by impurities (Arnal et al., 1999; Freeman et al., 1999), as the standard and target RNA are simultaneously reverse-transcribed and amplified in the same tube. One drawback of competitive RT-PCR is the requirement of an internally modified RNA standard, whose construction can be a time- and cost-consuming process.

A new CE method using an uncoated capillary column and UV detection was developed to rapidly and accurately analyse RT-PCR products. To the best of our knowledge, this is the first use of an uncoated capillary to quantitatively analyse PCR products, even though there have been several attempts to qualitatively separate DNA fragments (Gao and Yeung, 1998; Zhang and Yeung, 1998; Shihabi, 1999; Chiari et al., 2000). Analysis of DNA in silica capillary columns requires suppression of both electroosmotic flow (EOF) and wall interaction of DNA with capillary walls (Chiari et al., 2000), which can be achieved by coating the column. Commercially available coated capillary columns are expensive and can have short life times caused by deterioration of the coating material. Shihabi (1999) described successful DNA separations in

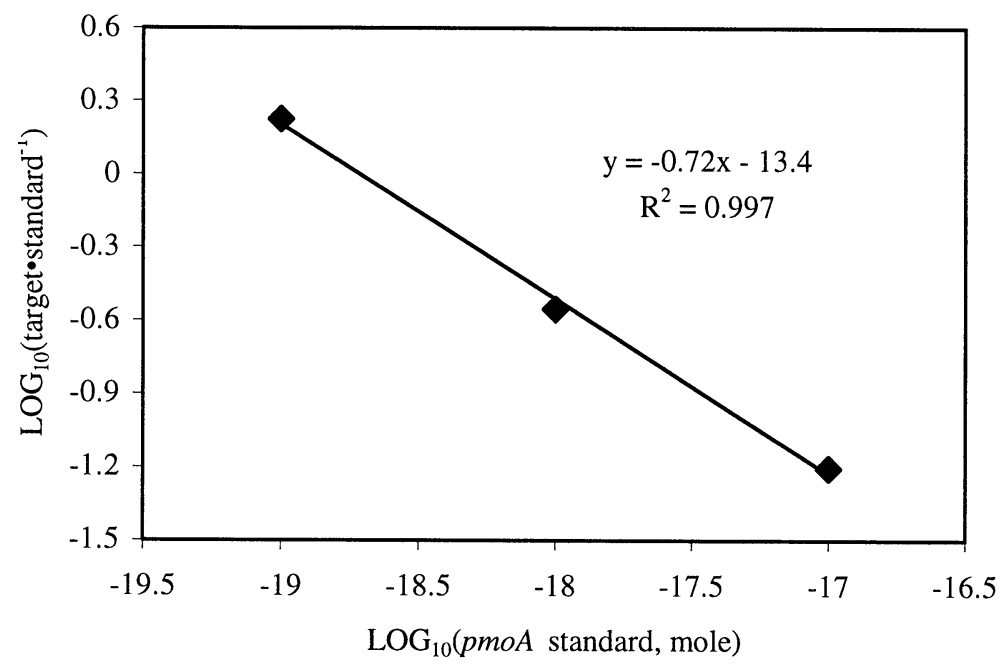

Fig. 8. Competitive RT-PCR of $p m o A$ from Wagner soil incubated with $M$. trichosporium OB3b. 
uncoated capillaries using HPMC as a sieving agent and a HEPES-borate buffer. It is possible that HPMC reduces EOF significantly and HEPES, a zwitterionic buffer, shields DNA against capillary wall interaction. However, preliminary results from our laboratory revealed that separation of double stranded DNA of varying size was only partially successful with these modifications (data not shown). This problem was resolved by the addition of $6 \%$ mannitol, which can interact with HPMC in the presence of boric acid to form a dynamic flexible network in the sieving matrix (Han et al., 1998). With this addition, DNA separation in uncoated capillaries appeared to be comparable to commercial coating columns, but the cost was greatly reduced. The addition of ethidium bromide helped to enhance UV detection as well as to separate DNA (Shihabi, 1999).

Using this CE methodology, the expression of $p m o A$ and $m m o X$ were successfully quantified in methanotrophs. From the data presented in Figs 3 and 4, it can be seen that the primer sets used could be used for methanotrophs from the a and $\gamma$ subdivisions of the Proteobacteria. Furthermore, using quantitative RT-PCR, we discovered that the mRNA transcript levels in $M$. trichosporium OB3b expressing either pMMO or sMMO varied linearly with rates of whole-cell methane consumption in the exponential growth phase. This cell expressing pMMO also had a linear relationship between mRNA levels and whole-cell methane consumption rates throughout different growth phases in a batch culture grown using sterile amended groundwater (Fig. 6), although a different relationship was discovered.

It should be noted that these results, although interesting as they show a strong correlation between mRNA transcript and whole-cell methane consumption, are only reported here for $M$. trichosporium OB3b. It is possible that the activity of other methanotrophs will also vary linearly in response to mRNA transcript levels of $p m o A$ and $m m o X$, but the magnitude of such a response may be different for different cells. Further work is ongoing to investigate how the expression of these genes is related to whole-cell methane oxidation in other methanotrophs. In any event, it appears based on the results presented here, the relationship between mRNA levels and wholecell activity, although linear, is strongly dependent on growth conditions, most notably the availability of copper as evidenced by the slope of the best-fit lines of Fig. 5A and 6C.

Finally, quantitative RT-PCR was performed in the presence of a model soil to extend the utility of this technique to environmental samples. Quantitative RNA extractions from soils are challenging as a result of compounded inefficiencies in the individual steps, including incomplete cell lysis, RNA degradation by ubiquitous RNases, sorption to soil surfaces, and co-extraction of enzymatic inhib- itors, mostly humic materials (Lorenz and Wackernagel, 1987; Moran et al., 1993; Alm and Stahl, 2000). The model soil used here, Wagner soil, had a relatively low organic content, but served well as a model system for the validation of our techniques, and can be applied to other systems. For soils with high organic content this technique can be modified to incorporate more purification steps to remove humic materials. Such modifications have been done by others for the successful RT-PCR of RNA in compost and digestor waste with high organic content (Burstcher and Wuertz, 2003) but not to our knowledge in the simultaneous presence of soils.

One major problem of quantitative RNA extraction regardless of the soil content is the sorption of RNA to soil surfaces and this adsorption becomes more problematic if conditions are extreme such as basic or acidic $\mathrm{pH}$ and high salt concentrations (Lorenz and Wackernagel, 1987; Ogram et al., 1994; Melzak et al., 1996). Unfortunately, RNA extraction buffers typically utilize high salt conditions to inactivate RNases and acidic conditions to selectively isolate RNA from DNA (Chomczynski and Sacchi, 1987).

A silica-based spin column method, in which RNA samples are bound onto a silica column in an extraction buffer, washed, and finally eluted with RNase-free water offers is an attractive option for isolation of mRNA from soils. Even though this approach also utilizes high salt concentrations, it has key advantages of being rapid and loss of the RNA pellet is reduced as nucleic acid precipitation is unnecessary. With this approach, RNA can be effectively extracted from soils by collecting RNA also sorbed on soil surfaces. The RNA recovery from soil was made possible by rinsing this soil matrix with DEPC-treated water, facilitating the release of adsorbed nucleic acids from soils (Lorenz and Wackernagel, 1987; Melzak et al., 1996). That is, for collection of RNA in the presence of Wagner soil, the soil itself was used as an additional binding matrix on which RNA could adsorb and then be subsequently recovered after washing away organic contaminants.

A simple, rapid, and effective RNA extraction technique from soils is particularly important when determining in situ methanotrophic activity. Gross in situ measurements of methanotrophic activity such as methane consumption rates do not provide any information as to what form of MMO these cells may be expressing unless coupled with a specific inhibitor of SMMO activity (Lontoh et al., 2000). Because $\mathrm{pMMO}$ and sMMO have very different substrate ranges and kinetics, what form of $\mathrm{MMO}$ is being expressed in different environments is a critical question when utilizing these communities for bioremediation of pollutants. Here, applying our RNA soil extraction technique coupled with RT-PCR and CE to a model soil system with $M$. trichosporium OB3b, we discovered only pMMO was being expressed. The copper concentration in 
this pore water was found to be $2.9 \mu \mathrm{M}$ using graphite furnace AAS. At this copper concentration, it is not surprising to find only $p m o A$ transcripts as $M$. trichosporium OB3b only expresses sMMO under conditions of copper limitation (Choi et al., 2003). It has been speculated that in at least one field study stimulating methanotrophs that pMMO was being expressed by the in situ population due to low rates of pollutant degradation (McCarty, 1997). The use of RT-PCR can help to verify that hypothesis as well quantify the level of expression, thus enabling one to better monitor these cells for the optimization of bioremediation strategies.

\section{Experimental procedures}

\section{Culture conditions in the presence and absence of soil}

Three methanotrophs, Methylomicrobium album BG8, Methylosinus trichosporium OB3b, and Methylococcus capsulatus Bath were grown on nitrate mineral salt (NMS) medium (Whittenbury et al., 1970) at $30^{\circ} \mathrm{C}\left(37^{\circ} \mathrm{C}\right.$ in the case of $M$. capsulatus Bath) in batch flasks shaken at 250 r.p.m. in a methaneair mixture (1:2 ratio) at $1 \mathrm{~atm}$ total pressure. The culture medium was no more than $15 \%$ of the total flask volume to prevent mass transfer limitations of methane and oxygen from the headspace to liquid medium. Methylosinus trichosporium OB3b and $M$. capsulatus Bath can express either sMMO or pMMO depending on copper bioavailability. Therefore, copper concentration was controlled very carefully in all experiments. For sMMO expression, copper was not added to the growth medium. To induce pMMO expression in these cells as well as for growth of M. album BG8, $10 \mu \mathrm{M}$ Cu was added aseptically as $\mathrm{Cu}\left(\mathrm{NO}_{3}\right)_{2} .5\left(\mathrm{H}_{2} \mathrm{O}\right)$ after autoclaving and was equilibrated for at least 2 days before the media were inoculated.

Methylosinus trichosporium OB3b was also grown in sterile groundwater collected from an aquifer at Bachman, MI. The groundwater was sterilized via autoclaving and NMS medium added to achieve a final concentration of $0.1 \times$. The growth of these cells was in this medium was monitored using a Spectronic Genesys (Thermo Electron, Waltham, MA) and side arm flasks such that the flasks did not need to be opened for monitoring growth, thereby maintaining consistent amounts of methane and oxygen during growth over several days.

Soil from Wagner, Michigan, an aquifer sandy soil containing $1.5 \mathrm{mg}$ organic matter $\cdot(\mathrm{g} \text { dry } \mathrm{wt})^{-1}$ was prepared as a model soil system (Huang et al., 1997). After autoclaving the soil for $1 \mathrm{~h}, 3 \mathrm{~g}$ was equilibrated with $3 \mathrm{ml}$ of NMS medium without further addition of copper for 3 days at $30^{\circ} \mathrm{C}$ in $20 \mathrm{ml}$ vials. These samples were then inoculated with $0.1 \mathrm{ml}$ of $M$. trichosporium OB3b grown in the absence of copper, sealed with Teflon-coated septa and incubated at $30^{\circ} \mathrm{C}$ in the presence of methane and air ( $1: 2$ ratio) at 1 atm of pressure with gentle agitation at 150 r.p.m. To determine the aqueous concentration of copper, the slurry was centrifuged at 12000 r.p.m. for $5 \mathrm{~min}$ and the supernatant was then measured for total copper by atomic absorption spectrophotometry (AAS, Perkin-Elmer).

\section{Total RNA extraction from pure cultures}

Care was taken in handling RNA to prevent RNA degradation by RNases. RNase-free disposable plasticware was used as well as glassware oven-baked at $240^{\circ} \mathrm{C}$ for $4 \mathrm{~h}$. All solutions were made with RNase-free compounds and diethyl pyrocarbonate (DEPC, Sigma)-treated water. In the absence of soils, methanotrophic cultures were pelleted by centrifugation at 12000 r.p.m. for $5 \mathrm{~min}$ at $4^{\circ} \mathrm{C}$. The supernatant was removed and the cell pellet was directly used in the total RNA isolation procedure or frozen and stored at $-80^{\circ} \mathrm{C}$ for later analysis. RNA extractions were performed using QIAGEN Total RNeasy kit (QIAGEN, Valencia, CA). Cells were first resuspended in the extraction buffer with $1.6 \mathrm{~g}$ of ice-cooled $0.1 \mathrm{~mm}$ diameter zirconia/silica beads (BioSpec products, Bartlesville. OK). Cell lysis was then performed by bead-beating in a MiniBead Beater (BioSpec products, Bartlesville, OK) six times at $30 \mathrm{~s}$, with $1 \mathrm{~min}$ on ice between each cycle. After cells were disrupted, RNA was isolated by first being treated with RNase-free DNase I (Promega) and total RNA extracted using the QIAGEN Total RNeasy kit.

\section{Total RNA extraction from Wagner soil}

Once noticeable methane consumption was observed in soil slurries as determined by gas chromatography (Han et al., 1999), $0.5 \mathrm{~g}$ was transferred to $2 \mathrm{ml}$ tubes, which were directly used in the total RNA isolation procedure or frozen and stored at $-80^{\circ} \mathrm{C}$ for later analysis. To ensure the quantitative extraction of high quality RNA from soils, the QIAGEN Total RNeasy protocol (QIAGEN, Valencia, CA) was modified. After cell lysis using bead beating, the soil/bead suspension was sampled by piercing the bottom of the tube with a 22 gauge sterile needle, placing it on top of a collection tube in a $15 \mathrm{ml}$ screw-cap polypropylene tube, and centrifuging for $5 \mathrm{~min}$ at $1500 \mathrm{~g}$ with a swing bucket centrifuge (model Centra-CL2; IEC, Needham Heights, MA). In this way, most of the extraction buffer containing the disrupted cells was recovered in the collection tube along with small soil particles, while zirconia/silica beads and large soil particles remained in the sample tube. One volume of $70 \%$ ethanol was then added to the suspension. This suspension was then passed through a QIAGEN column via relatively slow centrifugation (4000 r.p.m) to prevent suspended solids from passing through the column. After removing impurities using the QIAGEN washing buffers, total RNA was collected with $0.1 \mathrm{ml}$ DEPC-treated $\mathrm{H}_{2} \mathrm{O}$. Because the final volume was sufficiently small, a concentration step was not necessary. After being treated with RNase-free DNase I (Promega) to remove the DNA template, total RNA was extracted with the QIAGEN Total RNeasy kit.

\section{Synthesis of standard RNA for competitive RT-PCR}

To ensure consistent amplification efficiency of both target and standard, homologous internal RNA standards were designed with similar base sequences that could be amplified with the same primers used for target mRNA. Chromosomal DNA was used as a template for PCR amplification using PCR in site-directed mutagenesis by overlap extension, in 
Table 1. Primer sequences used for RT-PCR of $p m o A$ and $m m o X$ target and standard transcripts as well as mRNA standard construction.

\begin{tabular}{lll}
\hline Primer & Sequence $\left(5^{\prime}(r) 3^{\prime}\right)^{\mathrm{a}}$ & Reference \\
\hline pmoA & & \\
Forward & GGGGGACTTCTGGGGITGGAC & Cheng et al. (1999) \\
Reverse & GGGGGRCACGTCYTTACCGAA & Cheng et al. (1999) \\
T7 promoter-forward & TAATACGACTCACTATAGG- & This study \\
Reverse-Inner reverse & --AACTTCTGGGGITGGAC & This study \\
mmoX & ACAACGTCYTTACGAA- & \\
\hline Forward & - -ATTCCGGCATCGACGTGCGG & McDonald et al. (1995) \\
Reverse & & McDonald et al. (1995) \\
T7 promoter-forward & GGCTCCAAGTTCAAGGTCGAGC & This study \\
Reverse-Inner reverse & TGGCACTCGTAGCGCTCCGGCTCG & This study \\
& TAATACGACTCACTATAGG- & \\
\hline
\end{tabular}

a. $\mathrm{R}=\mathrm{A}$ or $\mathrm{G} ; \mathrm{Y}=\mathrm{C}$ or $\mathrm{T} ; \mathrm{I}=$ deoxyinosine.

which the T7 RNA polymerase promoter sequence was appended to the forward primers for both $p m o A$ and $m m o X$ and small portions of DNA fragments (58 bp for $p m o A$ and $90 \mathrm{bp}$ for $m m o X$ ) deleted using reverse-inner reverse primers as shown in Table 1. The PCR products were then visualized on gel electrophoresis and the corresponding bands were excised and purified using QIAGEN QIAspin columns according to manufacturer's guides (QIAGEN). In vitro transcription and DNase treatment were performed using the Riboprobe T7 in vitro transcription system following the manufacturer's instructions (Promega). RNA was then extracted using the RNeasy total RNA kit according to manufacturer's guidelines (QIAGEN). The quantity and quality of the transcribed RNA standards were determined by measuring the absorbance at $260 \mathrm{~nm}$ and $280 \mathrm{~nm}$. To ensure that the RNA standards excluded DNA contaminants, which could contribute to the internal standards and be amplified by RT-PCR, PCR reactions with and without reverse transcription (RT) step were run. No products were detected from PCR without RT, while the expected products were detected from RT-PCR (data not shown).

\section{Competitive RT-PCR assay}

Reverse transcription-PCR assays were performed with the QIAGEN OneStep RT-PCR kit (QIAGEN, Valencia, CA). The RT-PCR reaction was carried out in $50 \mu$ l consisting of $5 \mu \mathrm{l}$ of standard RNA, $5 \mu$ l total RNA, $10 \mu \mathrm{l} 5 x \mathrm{RT}$-PCR buffer, $10 \mu \mathrm{l} 5 \mathrm{xQ}$ solution, $400 \mu \mathrm{M}$ each of dNTPs, $0.6 \mu \mathrm{M}$ of each primer, and $2 \mu$ of QIAGEN OneStep RT-PCR enzyme. The sequences of steps to reverse transcribe and amplify both targets and standards were as follows. Following RT incubation at $50^{\circ} \mathrm{C}$ for $30 \mathrm{~min}$ and then heating to $95^{\circ} \mathrm{C}$ for $15 \mathrm{~min}, \mathrm{PCR}$ cycles (33 cycles for pure culture samples and 40 cycles for soil samples) were conducted at $94^{\circ} \mathrm{C}$ for $1 \mathrm{~min}$; $55^{\circ} \mathrm{C}$ for $1 \mathrm{~min}$; and $72^{\circ} \mathrm{C}$ for $1 \mathrm{~min}$. All samples were finally extended at $72^{\circ} \mathrm{C}$ for $10 \mathrm{~min}$. Polymerase chain reaction products were analysed either qualitatively by electrophoresis in $2.5 \%$ agarose gels or quantitatively by capillary electrophoresis (CE).

\section{CE analysis of RT-PCR products}

The analysis of PCR products by $C E$ was performed on a $\mathrm{P} /$ ACE MDQ instrument from Beckman (Beckman Instruments, Palo Alto, CA, USA) in the reverse polarity mode with $4 \mathrm{kV}$ applied voltage. Uncoated silica capillaries with $21 \mathrm{~cm}$ effective length and $31 \mathrm{~cm}$ total length $(75 \mu \mathrm{m}$ I.D) were used. The separation/flush buffer consisted of $50 \mathrm{mM}$ HEPES sodium salt ( $N$-2-hydroxyethylpiperazine- $N$-2-ethanesulfonic acid), $65 \mathrm{mM}$ boric acid, $0.5 \%$ hydroxypropylmethylcellulose (HPMC), 6\% mannitol and $1 \mu^{-1} \mathrm{ml}^{-1}$ ethidium bromide. The buffer was degassed by sonication. Before a run, the capillary column was rinsed sequentially with $0.2 \mathrm{~N} \mathrm{NaOH}, 0.2 \mathrm{~N} \mathrm{HCl}$, and finally the separation buffer for $3 \mathrm{~min}$ each. Samples were applied by pressure injection for $50 \mathrm{~s}$, at 1 psi. The ultraviolet absorbance was monitored at $254 \mathrm{~nm}$. To quantify RT-PCR products, peak areas on the resulting electropherogram were calculated by P/ACE Station software (V.1.0, Beckman Instruments, Palo Alto, CA, USA).

\section{Correlation of gene transcript levels with rates of whole- cell methane consumption}

For the assessment of the level of mmoX and pmoA transcripts vs. whole-cell methane oxidation rates, $M$. trichosporium OB3b was either grown in either 0 or $10 \mu \mathrm{M}$ copper. Throughout the exponential and stationary growth phases, cells were collected and the initial rates of whole-cell level of methane consumption measured as previously described (Han et al., 1999) with an initial methane concentration of $40 \mu \mathrm{M}$. From these same samples mRNA was extracted and quantified using competitive RT-PCR.

To determine the effect of different growth conditions including growth phase and growth medium, M. trichosporium OB3b was also grown on sterile groundwater collected from Bachman, MI and amended with NMS medium as described earlier. Aqueous samples $(10 \mathrm{ml})$ were collected periodically during growth at $86 \mathrm{~h}$ (exponential phase), $119 \mathrm{~h}$ (stationary phase), and $196 \mathrm{~h}$ (presumably death phase), through a rubber stopper using sterile $\mathrm{ml}$ syringes with 21 
gauge needles to ensure the flasks remained gas-tight. These samples were then assayed for methane consumption and mRNA as described above. Furthermore, the number of living cells in these samples was determined by spread plating on NMS plates and counting the number of colony forming units that formed after one week at $30^{\circ} \mathrm{C}$ on serial dilution plates ranging from $1: 1$ to $1: 10^{-7}$.

\section{Acknowledgement}

Research support from the National Science Foundation (MCB-9708557) to J.D.S. is gratefully appreciated.

\section{References}

Alfreider, A., Vogt, C., and Babel, W. (2003) Expression of chlorocatechol 1,2-dioxygenase and chlorocatechol 2,3dioxyegnase genes in chlorobenzene-contaminated subsurface samples. Appl Environ Microbiol 69: 1372-1376.

Alm, E.W., and Stahl, D.A. (2000) Critical factors influencing the recovery and integrity of rRNA extracted from environmental samples: use of an optimized protocol to measure depth-related biomass distribution in freshwater sediments. J Microbiol Meth 40: 153-162.

Arnal, C., Ferre-Aubinmeau, V., Mignotte, B., Imbert-Marcille, B.-M., and Billaudel, S. (1999) Quantification of hepatitis A virus in shellfish by competitive reverse transcription-PCR with coextraction of standard RNA. Appl Environ Microbiol 65: 322-326.

Beck, A., Lehmann, R., Gambaro, G., Häring, H.-U., Schleicher, E.D., Voelter, W., and Ceol, M. (1999) Advances in reverse transcription polymerase chain reaction analysis of cellular mRNA levels of transforming growth factor- $\beta 1$ by capillary electrophoresis with laser-induced fluorescence detection. Clin Chem Laboratory Med 37: 527-532.

Bogan, B.W., Schoenike, B., Lamar, R.T., and Cullen, A. (1996) Mangenase peroxidase mRNA and enzyme activity levels during bioremediation of polycyclic aromatic-hydrocarbon contaminated soil with Phanerochaete chrysporium. Appl Environ Microbiol 62: 2381-2386.

Borneman, J., and Triplett, E.W. (1997) Rapid and direct method for extraction of RNA from soil. Soil Biol Biochem 29: $1621-1624$.

Bürgmann, H., Widmer, F., Sigler, W.V., and Zeyer, J. (2003) mRNA extraction and reverse transcription-PCR protocol for detection of nifH gene expression by Azotobacter vinelandii in soil. Appl Environ Microbiol 69: 1928-1935.

Burrows, K.J., Cornish, A., Scott, D., and Higgins, I.J. (1984) Substrate specificities of the soluble and particulate methane mono-oxygenases of Methylosinus trichosporium OB3b. J Gen Microbiol 130: 3327-3333.

Burstcher, C., and Wuertz, S. (2003) Evaluation of the use of PCR and reverse transcriptase PCR for detection of pathogenic bacteria in biosolids from anaerobic digestors and aerobic composters. Appl Environ Microbiol 69: 46184627.

Cheng, Y.S., Halsey, J.L., Fode, K.A., Remsen, C.C., and Collins, M.L.P. (1999) Detection of methanotrophs in groundwater by PCR. Appl Environ Microbiol 65: 648-651.

Chiari, M., Cretich, M., and Horvath, J. (2000) A new adsorbed coating for DNA fragment analysis by capillary electrophoresis. Electrophoresis 21: 1521-1526.

Choi, D.W., Kunz, R.C., Boyd, E.S., Semrau, J.D., Antholine, W.E., Han, J.L. et al., (2003) The membrane-associated methane monooxygenase (pMMO) and pMMO-NADH: quinone oxidoreductase complex from Methylococcus capsulatus Bath. J Bacteriol 185: 5755-5764.

Chomczynski, P., and Sacchi, N. (1987) Single-step method of RNA isolation by acid guanidinium thiocyanate-phenolchloroform extraction. Anal Biochem 162: 156-159.

Ferre, F. (1992) Quantitative or semi-quantitative PCR: reality versus myth. PCR Meth Appl 2: 1-9.

Fleming, J.T., Yao, W.-H., and Sayler, G.S. (1998) Optimization of differential display of prokaryotic mRNA: application to pure culture and soil microcosms. Appl Environ Microbiol 64: 3698-3706.

Freeman, W.M., Walker, S.J., and Vrana, K.E. (1999) Quantitative RT-PCR: pitfalls and potential. Biotechniques 26: 112-125.

Gao, Q., and Yeung, E.S. (1998) A matrix for DNA separation: genotyping and sequencing using poly (vinylpyrrolidone) solution in uncoated capillaries. Anal Chem 70: 1382-1388.

Han, F., Xue, J., and Lin, B. (1998) Mannitol influence on the separation of DNA fragments by capillary electrophoresis in entangled polymer solutions. Talanta 46: 735-742.

Han, J.-I., Lontoh, S., and Semrau, J.D. (1999) Degradation of chlorinated and brominated hydrocarbons by Methylomicrobium album BG8. Arch Microbiol 172: 393-400.

Hanson, R.S., and Hanson, T.E. (1996) Methanotrophic bacteria. Microbiol Rev 60: 439-471.

Hill, G.T., Mitkowski, N.A., Aldrich-Wolfe, L., Emele, E.R., Jurkonie, D.D., Ficke, A. et al. (2000) Methods for assessing the composition and diversity of soil microbial communities. Appl Soil Ecol 15: 25-36.

Huang, W., Young, T.M., and Schlautman, M.A., Yu, H., and Weber, W.J. (1997) A distributed reactivity model for sorption by soils and sediments. 9. General isotherm nonlinearity and applicability of the dual reactive domain model. Environ Sci Technol 31: 1703-1710.

Kreader, C.A. (1996) Relief of amplification inhibition in PCR with bovine serum albumin or T4 gene 32 protein. Appl Environ Microbiol 62: 1102-1106.

Kusher, S.R. (1996) mRNA decay. In Escherichia Coli and Salmonella: Cellular and Molecular Biology, Vol. 1. Neidhardt, F.C., Curtiss, R., Ingraham, J.L., Lin, E.C.C., Low, K.B., Magasanik, B., et al. (eds). Washington, DC: American Society for Microbiology, pp. 849-860.

Lehmann, R., Voelter, W., and Liebich, H.M. (1997) Capillary electrophoresis in clinical chemistry. J Chromatogr B 697: 3-35.

Lindahl, T. (1993) Instability and decay of the primary structure of DNA. Nature 362: 709-715.

Lontoh, S., DiSpirito, A.A., Krema, C.L., Whittaker, M.R., Hooper, A.B., and Semrau, J.D. (2000) Differential inhibition in vivo of ammonia monooxygenase, soluble methane monooxygenase, and membrane-associated methane monooxygenase by phenylacetylene. Environ Microbiol 2: 485-494.

Lorenz, M.G., and Wackernagel, W. (1987) Adsorption of DNA to sand and variable degradation rates of adsorbed DNA. Appl Environ Microbiol 53: 2948-2952. 
McCarty, P.L. (1997) Aerobic cometabolism of chlorinated aliphatic hydrocarbons. In Subsurface Restoration. Ward, C.H., Cherry, J.A., Scalf, M.R, (eds). Ann Arbor, MI: Ann Arbor Press, pp. 373-395.

McDonald, I.R., Kenna, E.M., and Murrell, J.C. (1995) Detection of methanotrophic bacteria in environmental samples with the PCR. Appl Environ Microbiol 61: 116-121.

McDonald, I.R., and Murrell, J.C. (1997) The particulate methane monooxygenase gene pmoA and its use as a functional gene probe for methanotrophs. FEMS Microbiol Lett 156: 205-210.

Meckenstock, R., Steinle, P., van der Meer, J.R., and Snozzi, M. (1998) Quantification of bacterial mRNA involved in degradation of 1,2,4-trichlorobenzene by Pseudomonas sp. strain P51 from liquid culture and from river sediment by reverse transcriptase PCR (RT/PCR). FEMS Microbiol Lett 167: 123-129.

Melzak, K.A., Sherwood, C.S., Turner, R.F.B., and Haynes, C.A. (1996) Driving forces for DNA adsorption to silica in perchlorate solutions. J Colloid Interface Sci 181: 635644.

Miskin, I.P., Farrimond, P., and Head, I.M. (1999) Identification of novel bacterial lineages as active members of microbial populations in a freshwater sediment using a rapid RNA extraction procedure and RT-PCR. Microbiology 145: 1977-1987.

Moran, M.A., Torsvik, V.L., Torsvik, T., and Hodson, R.E. (1993) Direct extraction and purification of rRNA for ecological studies. Appl Environ Microbiol 59: 915-918.

Murrell, J.C. (1992) Genetics and molecular biology of methanotrophs. FEMS Microbiol Rev 88: 233-248.

Murrell, J.C., McDonald, I.R., and Bourne, D.G. (1998) Molecular methods for the study of methanotroph ecology. FEMS Microbiol Ecol 27: 103-114.

Nogales, B., Timmis, K.N., Nedwell, D.B., and Osborn, A.M. (2002) Detection and diversity of expressed denitrification genes in estuarine sediments after reverse transcriptionPCR amplification from mRNA. Appl Environ Microbiol 68: 5017-5025.

Ogram, A.V., Mathot, M.L., Harsh, J.B., Boyle, J., and Pettigrew, C.A. (1994) Effects of DNA polymer length on its adsorption to soils. Appl Environ Microbiol 60: 393-396.

Oldenhuis, R., Vink, R.L.J.M., Janssen, D.B., and Witholt, B. (1989) Degradation of chlorinated aliphatic hydrocarbon by Methylosinus trichosporium OB3b expressing soluble methane monooxygenase. Appl Environ Microbiol 55: 2819-2826.

Rechards, M.P., Ashwell, C.M., and McMurtry, J.P. (2000) Quantitative analysis of leptin mRNA using competitive reverse transcription polymerase chain reaction and capillary electrophoresis with laser-induced fluorescence detection. Electrophoresis 21: 792-798.
Semrau, J.D., Chistoserdov, A., Lebron, J., Costello, A., Davignino, J., Kenna, E., et al. (1995) Particulate methane monooxygenase genes in methanotrophs. J Bacteriol 177: 3071-3079.

Sheridan, G.E.C., Masters, C.I., Shallcross, J.A., and Mackey, B.M. (1998) Detection of mRNA by reverse transcription-PCR as an indicator of viability in Escherichia coli cells. Appl Environ Microbiol 64: 1313-1318.

Shihabi, Z.K. (1999) Capillary electrophoresis of doublestranded DNA in an untreated capillary. $J$ Chromatogr $A$ 853: 349-354.

Spring, S., Schulze, R., Overmann, J., and Schleifer, K.-H. (2000) Identification and characterization of ecologically significant prokaryotes in the sediment of freshwater lakes: molecular and cultivation studies. FEMS Microbiol Rev 24: 573-590.

Stirling, D.I., Colby, J., and Dalton, H. (1979) A comparison of the substrate and electron-donor specificities of the methane monooxygenase from three strains of methaneoxidizing bacteria. Biochem J 177: 361-364.

Stolyar, S., Costello, A.M., Peeples, T.L., and Lidstrom, M.E. (1999) Role of multiple gene copies in particulate methane monooxygenase activity in the methane-oxidizing bacterium Methylococcus capsulatus Bath. Microbiology 145: 1235-1244.

Sunada, W.M., and Blanch, H.W. (1997) Polymeric separation media for capillary electrophoresis to the post-polymerase chain reaction analysis of nucleic acids. Electrophoresis 18: 2243-2254.

Tsai, S.J., and Wiltbank, M.C. (1998) Standard curve quantitative competitive RT-PCR (SC-QC-RT-PCR): a simple method to quantify absolute concentration of mRNA from limited amounts of sample. In Gene Cloning and Analysis by RT-PCR. Siebert, P.D., and Larrick, J.W., (eds). Westborough, MA: BioTechniques $®$ Books, Eaton Publishing, pp. 91-101.

Whittenbury, R.K., Philips, K.D., and Wilkinson, J.F. (1970) Enrichment, isolation and some properties of methaneutilizing bacteria. J Gen Microbiol 61: 205-218.

Wilson, S.S., Bakermans, C., and Madsen, E.L. (1999) In situ, real-time catabolic gene expression: extraction and characterization of naphthalene dioxygenase mRNA transcripts from groundwater. Appl Environ Microbiol 65: 8087.

von Wintzingerode, F., Gobel, U.B., and Stackebrandt, E. (1997) Determination of microbial diversity in environmental samples: pitfalls of PCR-based rRNA analysis. FEMS Microbiol Rev 21: 213-229.

Zhang, N., and Yeung, E.S. (1998) On-line coupling of polymerase chain reaction and capillary electrophoresis for automatic DNA typing and HIV-1 diagnosis. J Chromatogr B 714: 3-11. 